\title{
International Journal of Applied Research in Mechanical
}

\section{Engineering}

Volume 2 | Issue 3

Article 1

January 2013

\section{PERFORMANCE AND EMISSIONS OF C.I. ENGINE USING BLENDS OF BIODIESEL AND DIESEL AT DIFFERENT INJECTION PRESSURES}

\section{H. M. DHARMADHIKARI}

Department of Mechanical Engineering, Maharashtra Institute of Technology, Aurangabad (M.S.) India, hmdharmadhikari@gmail.com

Follow this and additional works at: https://www.interscience.in/ijarme

Part of the Aerospace Engineering Commons, and the Mechanical Engineering Commons

\section{Recommended Citation}

DHARMADHIKARI, H. M. (2013) "PERFORMANCE AND EMISSIONS OF C.I. ENGINE USING BLENDS OF BIODIESEL AND DIESEL AT DIFFERENT INJECTION PRESSURES," International Journal of Applied Research in Mechanical Engineering: Vol. 2: Iss. 3, Article 1.

DOI: 10.47893/IJARME.2013.1077

Available at: https://www.interscience.in/ijarme/vol2/iss3/1

This Article is brought to you for free and open access by the Interscience Journals at Interscience Research Network. It has been accepted for inclusion in International Journal of Applied Research in Mechanical Engineering by an authorized editor of Interscience Research Network. For more information, please contact sritampatnaik@gmail.com. 


\title{
PERFORMANCE AND EMISSIONS OF C.I. ENGINE USING BLENDS OF BIODIESEL AND DIESEL AT DIFFERENT INJECTION PRESSURES
}

\author{
H. M. DHARMADHIKARI ${ }^{1}$, PULI RAVI KUMAR ${ }^{2}$, S. SRINIVASA RAO ${ }^{2}$ \\ ${ }^{1}$ Department of Mechanical Engineering, Maharashtra Institute of Technology, Aurangabad (M.S.) India \\ ${ }^{2}$ Department of Mechanical Engineering, National Institute of Technology, Warangal (A.P.) India \\ ${ }^{1}$ Corresponding author; e-mail: hmdharmadhikari@gmail.com
}

\begin{abstract}
In recent years, much research has been carried to find suitable alternative fuel to petroleum products. In the present investigation experimental work has been carried out to analyze the performance and emissions characteristics of a single cylinder compression ignition DI engine fuelled with the blends of mineral diesel and biodiesel at the different injection pressures. The optimal value of the injection pressure was observed as 200 bar in the range of 180 to 220 bar. The performance parameters evaluated were brake thermal efficiency, break specific fuel consumption and the emissions measured were carbon monoxide $(\mathrm{CO})$, carbon dioxide $\left(\mathrm{CO}_{2}\right)$, hydrocarbon $(\mathrm{HC})$, and oxides of nitrogen $\left(\mathrm{NO}_{\mathrm{x}}\right)$. The results of experimental investigation with biodiesel blends with diesel are compared with that of diesel. The results indicated that the $\mathrm{CO}$ emissions are slightly less, $\mathrm{HC}$ emissions were also observed to be less for B10 and B20, and NOx emissions decreased by $39 \%$ for B10 and $28 \%$ for B20 compared with B100. The brake thermal efficiency of the engine decreased around $6 \%$ for all blends in comparison with diesel, and the break specific fuel consumption was slightly more for B10 and B20.
\end{abstract}

Keywords - biodiesel; diesel engine; karanja; neem oil methyl ester; injection pressure; performance; exhaust emissions

\section{INTRODUCTION}

In recent times, the world is confronted with the twin crisis of fossil fuel depletion and environmental degradations. The situations have led to the search for an alternative fuel which should be not only sustainable but also environment friendly without sacrificing the performance. The different sources for alternative fuels are edible- and non-edible vegetable oils, animal fats and waste oil (triglycerides). Vegetable oils, being renewable, are widely available from variety of sources have low sulfur contents close to zero and hence cause less environmental damage (lower green house effect) than diesel[1-4]. In the context of India, non edible vegetable oil can be the most viable alternative for petroleum fuels since there is shortage of edible oils to meet the domestic requirements [5, 6]. It has been found that neat vegetable oil can be used as a fuel in conventional diesel engines. However, unmodified vegetable oils are glycerol esters, and when used in diesel engines the glycerol poses engine wear and performance problems due to higher viscosity and lower volatility. To mitigate these problems, a variety of processes have been demonstrated for conversion of oil glycerides to molecular forms similar to petroleum based diesel fuels. Biodiesel is chemically defined as mono alkyl esters of FAME (Fatty Acid Methyl Ester) type derived from renewable lipid sources obtained from transesterification [7] reaction as represented following.

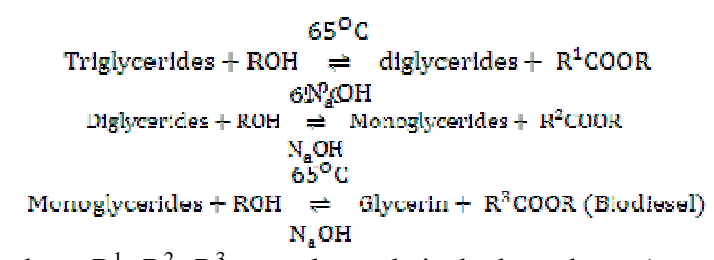

where $\mathrm{R}^{1}, \mathrm{R}^{2}, \mathrm{R}^{3}$ are long chain hydrocarbons (same or different) and $\mathrm{R}=\mathrm{CH}_{3}$
The glycerin being heavier settles down and the upper layer constitutes biodiesel. The reaction details of transesterification can be found elsewhere [7, 9-11].

\section{LITERATURE REVIEW}

Researchers from various parts of the world have carried large number of experiments with biodiesel as a replacement fuel for internal combustion engines. The name biodiesel was introduced in the United States during 1992 by National Biodiesel Board (NBB) which pioneered its commercialization. Biodiesel is currently defined in the technical regulations EN 14214 or ASTM 6751-02[7].

Goering et al [12] studied the properties of different vegetable oils and modified fuels for automotive applications and reported that vegetable oils have acceptable cetane numbers (35-45), high viscosity (50 Cst) high flash points $\left(220-285^{\circ} \mathrm{C}\right)$ and high pour points (-6 to $12^{\circ} \mathrm{C}$ ) and appreciable heating values (about $90 \%$ of diesel ) and low sulfur content $(<0.02 \%)$.

Ziejwski et al (1984) fueled engine with sunflower derived biodiesel. Shrinivasa \& Gopalkrishnan (1984) used karanja based bio-diesel. Bio diesel's ability to reduce emission was recognized by Schumacher et al (1992) and reported reductions in smoke density when fueling biodiesel of Soybean oil. Christopher (1997) conducted two tests in Chicago using biodiesel as fuel. The testing proved that the biodiesel could be used as a feasible alternative fuel.

Masjuki and Prasad et al [3], have respectively used esterifed Palm oil to conduct experiments on diesel engine. Torque, brake power, SFC \& brake thermal efficiency were found comparable to that of diesel fueled engine. M. Senthilkumar [13], T. Ganapathy [14] and P.Ravi Kumar [15] has investigated methyl ester of jatropha oil as fuel and 
showed that transesterfication reaction improved the properties of the ester.

Emulations also find attraction to use as a fuel in diesel engines due to the reduction in smoke and NOx emission using oil water emulsion as fuel (Lin and Wang 2003) [16]. G. Amba Prasad \& P. R. Mohan (2003) have studied effect and supercharging on the biodiesel of Cotton seed oil on DI diesel engine. Ramdhas A.S. et al (2006) have experimented methyl ester of rubber seed oil on diesel engine. Rahman \& Ghadge (2007) [17] have concluded that mahua based biodiesel can be safely blended up to $20 \%$ with mineral diesel and could be a suitable alternative fuel. The similar conclusion is reached by Lin Y (2007) about waste oil based biodiesel.

The exhaust emission characteristics of diesel engines operated with biodiesels have been studied by many researchers. A review of research papers of Quick, Barsic and Lhumke revealed that with the use of biodiesel the harmful exhaust emission particularly $\mathrm{CO}$ and sulfur compounds are reduced as compared to mineral diesel operation.

Several researchers (Rahman, Phadtare 2004, Agrawal et al 2001, and Md Norun Nubi 2006 He Bao, Hamelinck) [11,17-22] have observed that the exhaust emissions are affected by the use of biodiesel. It is known that biodiesel generally causes on increase in NOx emission and decrease in unburned hydrocarbon ( $\mathrm{HC}), \mathrm{CO}$ and particulate matter (PM) emission relative to diesel fuel. However, there are a very few reports of study of performance and emissions characteristics of CIDI engine fueled on blends karanja biodiesel and neem biodiesel with diesel fuel optimizing the relevant working parameters.

India has rich and abundant forest resources with wide range of plants and oil seeds. The potential of tree borne oil seeds (TBO) is not fully explored. According to an economic survey of Government of India about 175 million hectors of land is classified as waste or barren land. Wild crops cultivated in waste land also form a source of biodiesel. Besides, some species of plants yielding non edible oils, like karanja also called honge (Pongamia pinnata) and neem (Azadirachta indica) may play significant role in providing resources. Country like India in tropical Asia is the primary habitat for neem and karanja crops. It is estimated that India alone has theoretical potential to produce 350,000 tons of neem oil per annum.

\section{OBJECTIVES}

The use of neem oil biodiesel (neem oil methyl ester, NOME) blended with mineral diesel or karanja oil biodiesel (karanja oil methyl ester, KOME) blended with mineral diesel as substitute for conventional mineral diesel (ASTM D2) in diesel engine is reasonable and prospective in India [5, 24, and 25]. For such a proposal, modification of diesel engine structure is unnecessary and expensive for large number of existing engines operating in rural sector, as confirmed by the literature. However, there are certain differences in physical and chemical characteristics of NOME / KOME and diesel oil. It is found that the oil mixture / blend will not ensure the desirable results unless the working parameters are readjusted according to the results of experimentation. The purpose of the investigation is to analyze the effects on diesel engine performance when fueled with the blends of biodiesel and diesel in various proportions on volume basis. The fuel blends investigated for performance analysis are $100 \%$ diesel (B00), blend of $10 \%$ biodiesel and $90 \%$ diesel (B10), blend of 20\% biodiesel and $80 \%$ diesel (B20), blend of $60 \%$ biodiesel and $40 \%$ diesel (B60), 100\% biodiesel (B100) for both of the biodiesels of neem oil and karanja oil. The experimentation further extended to procure most desirable values for the relevant working parameters and their optimal combination based on the results. The performance parameters like engine power, brake thermal efficiency, brake specific fuel consumption and exhaust emissions are considered for the discussions $[26,27]$.

\section{EXPERIMENTAL SETUP AND PROCEDURES}

\subsection{Engine}

Experiments were conducted on a Kirloskar AV-1 stationary diesel engine of the I.C.Engines laboratory. The specifications of test engine are given in table 1 .

Table 1: Specifications of test engine

\begin{tabular}{|c|c|}
\hline Particulars & Specifications \\
\hline Make & Kirloskar Oil Engines, India \\
\hline Type & $\begin{array}{l}\text { Naturally aspirated four stroke } \\
\text { compression ignition DI }\end{array}$ \\
\hline No. of cylinders & One \\
\hline Bore $\mathrm{x}$ Stroke & $80 \times 110 \mathrm{~mm}$ \\
\hline Cubic Capacity & 0.553 lit \\
\hline Compression Ratio & 16.5: 1 \\
\hline $\begin{array}{l}\text { Rated Output as per } \\
\text { BS5514/ISO } 3046\end{array}$ & $3.7 \mathrm{~kW}(5.0 \mathrm{hp})$ at $1500 \mathrm{rpm}$. \\
\hline $\begin{array}{l}\mathrm{SFC} \text { at rated } \\
\mathrm{hp} / 1500 \mathrm{rpm}\end{array}$ & 245 g/kWh (180g /bhp.hr) \\
\hline $\begin{array}{l}\text { Connecting rod } \\
\text { length }\end{array}$ & $230 \mathrm{~mm}$ \\
\hline Volume at TDC & $35 \mathrm{cc}$ \\
\hline Volume at BDC & $588 \mathrm{cc}$ \\
\hline $\begin{array}{l}\text { Engine Weight } \\
\text { (dry) }\end{array}$ & $114 \mathrm{~kg}$ \\
\hline Weight of flywheel & 33kg - Standard \\
\hline Starting & $\begin{array}{l}\text { Hand start with cranking } \\
\text { handle }\end{array}$ \\
\hline IVO / IVC & 4.50 BTDC / $35.50 \mathrm{ABDC}$ \\
\hline $\mathrm{EVO} / \mathrm{EVC}$ & 35.50 BBD / 4.50 ATDC \\
\hline
\end{tabular}

\subsection{Loading}

Engine loading is through electrical generator. A DC shunt generator with electrical load bank of bulbs is used. A rheostat is connected in series the circuit to control the load precisely by controlling voltage. The specifications of electrical generator are shown in table 2 .

Table 2: Specifications of electrical generator

\begin{tabular}{|l|l|}
\hline Particulars & Specifications \\
\hline Output & $5 \mathrm{~kW}$ \\
\hline RPM & 1440 \\
\hline Phase & Single \\
\hline Voltage & $230 \mathrm{~V}$ \\
\hline Current & $22 \mathrm{~A}$ \\
\hline
\end{tabular}

\subsection{Instrumentation}

The operating and performance parameters of the test engine were measured by direct or indirect output of different measuring instruments after their calibrations [27]. 
The specifications of different measuring devices are detailed in table 3 .

Table 3: Specifications of instruments

\begin{tabular}{|l|l|}
\hline Particulars & Specifications \\
\hline $\begin{array}{l}\text { Speed } \\
\text { measurement }\end{array}$ & $\begin{array}{l}\text { Mechanical Tachometer } \\
\text { Analogue Hand Tachometer } \\
\text { Model : LZ-30 } \\
\text { Range: } 30-12000 \mathrm{rpm} .\end{array}$ \\
\hline $\begin{array}{l}\text { Air flow } \\
\text { measurement }\end{array}$ & $\begin{array}{l}\text { Air box method } \\
\text { Orifice type with orifice diameter } 30 \mathrm{~mm} . \\
\text { Overall dimensions 2' } \mathrm{2} 2^{\prime} \times 2^{\prime}\end{array}$ \\
\hline $\begin{array}{l}\text { Temperature } \\
\text { measurement }\end{array}$ & $\begin{array}{l}\text { Thermocouples Range : }-100^{\circ} \mathrm{C} \text { to } 600^{\circ} \mathrm{C} \\
\text { Type : 'J', Length : 12" } \\
\text { Digital temperature indicator, Type }: \mathrm{FE} / \mathrm{K}\end{array}$ \\
\hline $\begin{array}{l}\text { Fuel } \\
\text { measurement }\end{array}$ & Burette and stop watch \\
\hline Voltmeter & $\begin{array}{l}\text { Make : Snipper, Range : 0-300 V } \\
\text { Scale : Non linear type }\end{array}$ \\
\hline Ammeter & $\begin{array}{l}\text { Make : Snipper, Range : 0-30 A } \\
\text { Resolution : 0.2 A }\end{array}$ \\
\hline
\end{tabular}

\subsection{Exhaust gas analyzer}

Exhaust gas composition was measured using NDIR based exhaust gas analyzer [AVL Austria; Model: Di-gas 444 Approved by ARAI, India and ISO 3930: 2000]. The analyzer measures $\mathrm{CO}, \mathrm{CO}_{2}, \mathrm{HC}, \mathrm{O}_{2}$ and $\mathrm{NO}_{\mathrm{x}}$ in the exhaust.

The range and accuracy of the AVL gas analyzer is given in table 4 .

Table 4: Specifications of AVL Di-gas 444 Analyzer

\begin{tabular}{|c|c|c|c|}
\hline $\begin{array}{c}\text { Exhaust } \\
\text { Gas }\end{array}$ & Range & Resolution & Accuracy \\
\hline $\mathrm{CO}$ & $\begin{array}{l}0-10 \% \\
\text { Volume }\end{array}$ & $\begin{array}{l}0.01 \% \\
\text { Volume }\end{array}$ & $\begin{array}{c}<0.6 \% \text { vol.: } \\
\pm 0.03 \% \\
\geq 0.6 \% \text { vol.: } \pm \\
5 \%\end{array}$ \\
\hline $\mathrm{HC}$ & $\begin{array}{l}0-20000 \\
\text { ppm }\end{array}$ & $\begin{array}{l}\leq 2000: 1 \mathrm{ppm} \\
\text { Volume } \\
> \\
2000: 10 \mathrm{ppm} \\
\text { Volume }\end{array}$ & $\begin{array}{c}<2000 \mathrm{ppm} \\
\text { vol.: } \pm 10 \\
\geq 2000 \mathrm{ppm} \\
\text { vol: } \pm 5 \%\end{array}$ \\
\hline $\mathrm{CO}_{2}$ & $\begin{array}{l}0- \\
20 \% \text { Volume }\end{array}$ & $0.1 \%$ Volume & $\begin{array}{c}<10 \% \text { vol.: } \pm \\
0.5 \% \text { vol. } \\
\geq 10 \% \text { vol.: } \pm \\
0.5 \%\end{array}$ \\
\hline $\mathrm{O}_{2}$ & $\begin{array}{l}0- \\
22 \% \text { Volume }\end{array}$ & $0.01 \%$ Volume & $\begin{array}{c}<2 \% \text { vol.: } \pm \\
0.1 \% \text { vol. } \\
\geq 2 \% \text { vol.: } \pm \\
5 \% \\
\end{array}$ \\
\hline $\mathrm{NO}_{\mathrm{x}}$ & $0-5000 \mathrm{ppm}$ & $1 \mathrm{ppm}$ volume & $\begin{array}{l}<500 \mathrm{ppm} \\
\text { vol.: } \pm 50 \\
\geq 500 \mathrm{ppm} \\
\text { vol: } \pm 10 \% \\
\end{array}$ \\
\hline
\end{tabular}

The exhaust pipe is modified as shown in the figure to help facilitate exhaust emission measurements to suit the probe insertion.

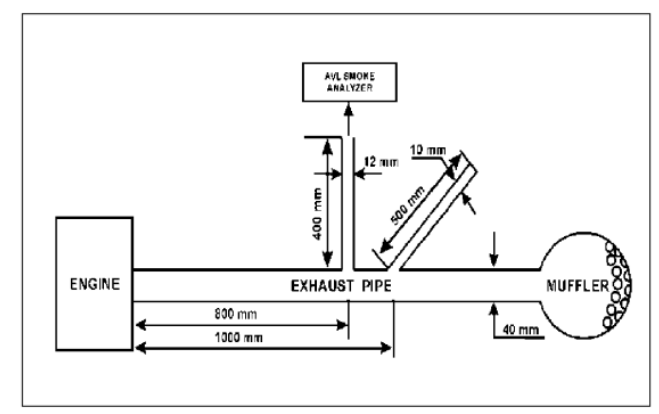

Figure 1 Modification in the exhaust pipe to facilitate emission measurement

\subsection{Arrangement}

The arrangement of experimental facility is represented schematically in following figure.

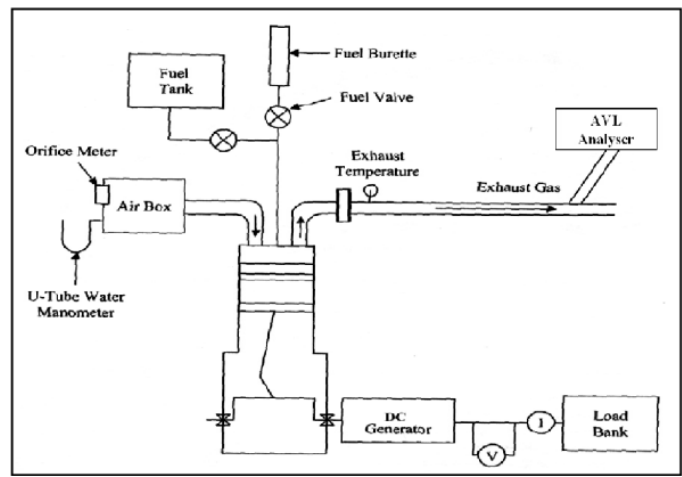

Figure 2 Schematic arrangement of experimental setup

\subsection{Test Methods}

The biodiesels of karanja and neem were supplied by the agricultural university. Trasesterfication of both the oils is composed of heating of, addition of catalyst sodium hydroxide $(\mathrm{NaOH})$ in methanol $\left(\mathrm{CH}_{3} \mathrm{OH}\right)$ in the specific molar ratio, stirring of mixture, separation of glycerol, and washing with distilled waters. This is the usual method used for making laboratory quantities of vegetable oil esters.

The biodiesel can be directly mixed with diesel fuel and is used for running the engine. The blend of biodiesel and diesel has density close to that of mineral diesel. The blends were prepared just before test to ensure mixture homogeneity on volume basis from $0 \%$ to $100 \%$ volume of biodiesel in mineral diesel at $38^{\circ} \mathrm{C}$. All measurements were performed on sample of $200 \mathrm{ml}$, without pretreatment. These blends were then subjected to the performance tests on the water cooled diesel engine coupled to the electric generator. The engine was operated at an injection pressure of 200 bar with static injection timings of $24^{0}$ BTDC at rated speed of $1500 \mathrm{rpm}( \pm 2 \%)$. The specifications of engine and generator are as furnished earlier in the text.

The engine started on a given fuel blend was allowed to run for $20 \mathrm{~min}$ to reach steady state conditions before noting the observations and readings for the incremental loads ranging from no load to full load. All observations are tabulated. For each loading the inlet air flow rate, the time for $30 \mathrm{cc}$ of fuel consumption, the ambient temperature, the exhaust gas temperature, the outlet cooling water flow rate and ammeter and volt meter readings were noted and experiments were repeated for the repeatability of the measurements. The injection pressures of the fuel was set by the adjusting the spring tension of the injector of fuel pump.

\subsection{Computed properties of blends}

Based on the properties of fuel as shown in Table 5, the properties of separate blends of KOME / NOME with diesel fuel in different proportions are estimated numerically.

Table 5: Properties of diesel and biodiesels

\begin{tabular}{|c|l|r|r|r|r|r|}
\hline Sl & Fuel & $\begin{array}{r}\text { Specif } \\
\text { ic }\end{array}$ & $\begin{array}{r}\text { Kinemat } \\
\text { ic }\end{array}$ & $\begin{array}{r}\text { Lower } \\
\text { calorif }\end{array}$ & $\begin{array}{r}\text { Flas } \\
\mathrm{h}\end{array}$ & $\begin{array}{r}\text { Cetan } \\
\mathrm{e}\end{array}$ \\
no & & gravit & viscosit & ic & poin & numb \\
& & $\mathrm{y}$ & $\begin{array}{r}\mathrm{y} \\
\text { value } \\
(\mathrm{cSt})\end{array}$ & $\mathrm{t}$ & $\mathrm{er}$ \\
& & & $\mathrm{MJ} / \mathrm{k}$ & $\left({ }^{\circ} \mathrm{C}\right)$ & \\
\hline
\end{tabular}


Performance and Emissions of c.i. Engine using Blends of Biodiesel and Diesel at Different Injection Pressures

\begin{tabular}{|l|l|r|r|r|r|r|}
\hline 1 & & & & g) & & \\
\hline 2 & $\begin{array}{l}\text { Diese } \\
1\end{array}$ & 0.846 & 2.60 & 42.21 & 52 & 50 \\
$\begin{array}{l}\text { KOM } \\
\text { B100 } \\
\text { ) }\end{array}$ & 0.876 & 9.60 & 36.12 & 187 & 55 \\
\hline 3 & $\begin{array}{l}\text { NOM } \\
\text { E } \\
\text { (B10 } \\
0)\end{array}$ & 0.873 & 3.20 & 39.60 & 160 & 53 \\
\hline
\end{tabular}

\section{RESULTS AND DISCUSSION}

Experimental investigation were carried out for performance and exhaust emission of the engine for blends of diesel and methyl ester of karanja and neem oil in various proportions as fuel and are compared with mineral diesel. The performance was done according to BIS: 5994

\subsection{Viscosity and density}

Kinematic viscosity and density at room temperature of different blends of Neem oil methyl ester and Karanja oil methyl ester are higher than that of diesel. The blends of NOME / KOME with diesel in smaller proportion have physical properties closer to that of diesel. The higher densities of blends (B60 and B100) can be reduced by heating.

\subsection{Brake thermal efficiency (BTE)}

The BTE of different fuels is shown as a function of load. The variation in brake thermal efficiency for various blends was less than at part load than at higher load due to the raised temperatures inside the cylinder. The brake thermal efficiencies of diesel and the blends of biodiesel with diesel were seen increased with increase in load but tended to decrease with further increase in load. The BTE of blends were lower than with diesel throughout the entire range showing the poor combustion characteristics of methyl ester due to high viscosity and poor volatility. The BTE of $\mathrm{B} 10, \mathrm{~B} 20$ of KOME / NOME are closer to that of diesel. At full load conditions BTE of B20 KOME is about 5\% less than that of diesel. The BTE of B10, B20 of KOME/NOME are found better.
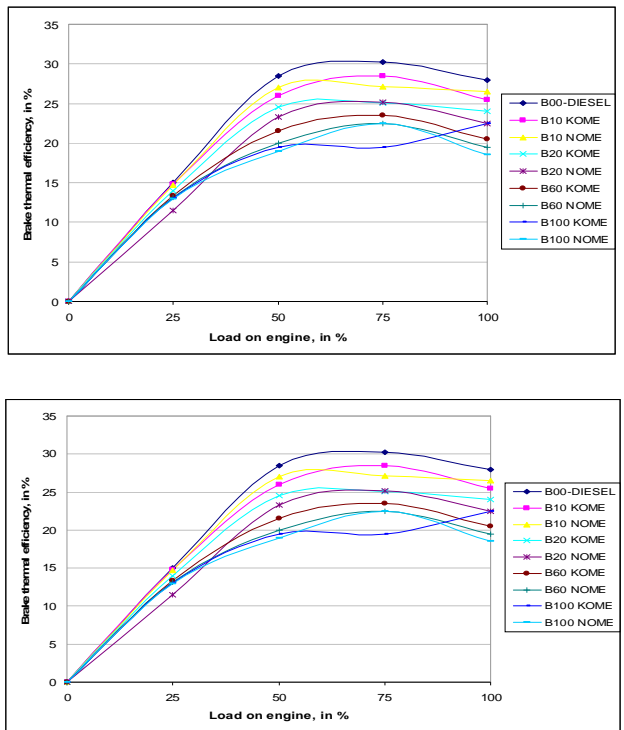

Figure 3 Comparison of variation of brake thermal efficiency with load on engine

\subsection{Brake specific fuel consumption (BSFC)}

The variation in brake specific fuel consumption with load for different fuels shows decline with increase in load. One possible explanation for this could be due to more increase in brake power with load as compared with fuel consumption. The BSFC in case of blends were higher compared to diesel in the entire load range, due to its lower heating value, greater density and hence higher bulk modulus. The higher bulk modulus results in more discharge of fuel for same displacement of the plunger in injection pump, there by resulting increase in BSFC.

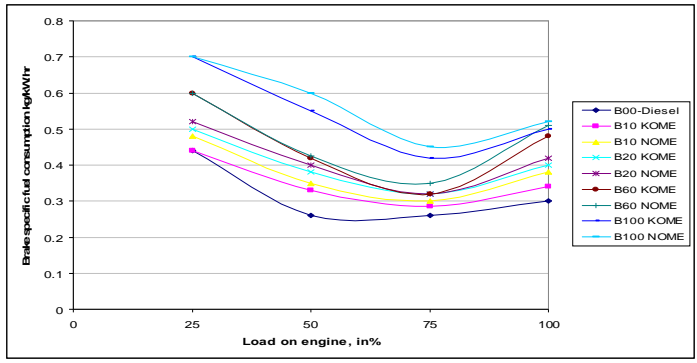

Figure 4 Comparison of variation of brake specific fuel consumption with load

\subsection{Exhaust gas temperature}

It is evident from the graph that exhaust gas temperature is increased along with the increase in load for all fuels. The mean temperature increased linearly for $150^{\circ} \mathrm{C}$ at no load to $350^{\circ} \mathrm{C}$ at full load with average increase of $30 \%$ with $25 \%$ increase in load. The increase in exhaust gas temperature with load is obvious from the fact that more fuel is required to take additional load. The exhaust gas temperature was found to increase with increasing concentration of biodiesel in the blends. This could be due to lower heat transfer rate in case of biodiesel which in evident from trends of thermal efficiency.

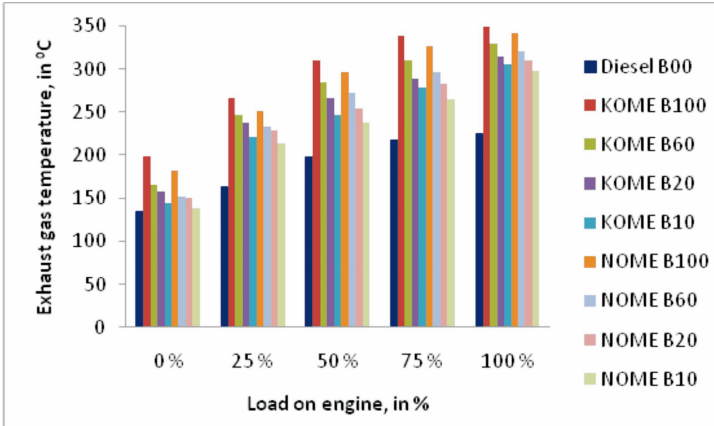

Figure 5 Comparison of variation of exhaust gas temperature with load

\subsection{Emissions of Nitrogen Oxides $\left(\mathrm{NO}_{x}\right)$}

The $\mathrm{NO}_{\mathrm{x}}$ values as parts per million for different blends of diesel and biodiesel in exhaust emission are plotted as function of load. From these figures it can be seen that the fueling biodiesel or its blends increase $\mathrm{NO}_{\mathrm{x}}$ emission slightly $5-10 \%$ compared with that of diesel. These could be attributed to

a) Increase exhaust gas temperature due to lower heat transfer and the fact that biodiesel has some oxygen content in it which facilitates $\mathrm{NO}_{\mathrm{x}}$ formation.

b) An advance of fuel injection timings in engine operating on mechanical type fuel injectors when using biodiesels which are having lower compressibility compared to diesel thus lower compressibility and higher 
speed of sound in biodiesel shorten ignition delay permitting can combustion conditions conducive for $\mathrm{NO}_{\mathrm{x}}$ formation.

c) Higher cetane number of biodiesel shortens ignition delay advancing combustion.

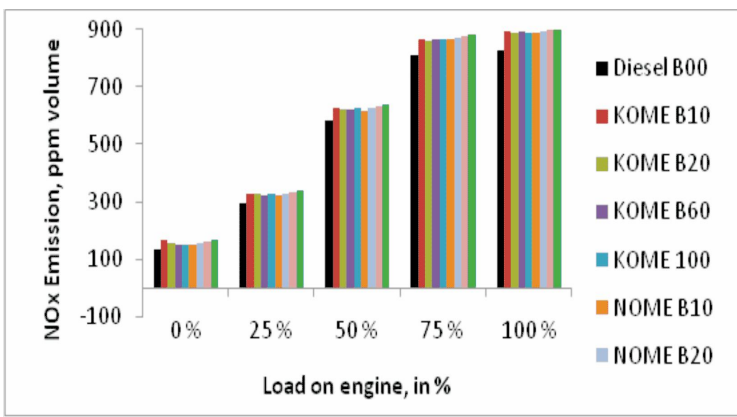

Figure 6 Comparison of variation of $\mathrm{NO}_{\mathrm{x}}$ emissions with load

\subsection{Exhaust emission of Carbon Monoxide (CO)}

Figure shows the variation of $\mathrm{CO}$ emission with engine loading. It was observed that $\mathrm{CO}$ emissions are increased with increase in engine load. The lower $\mathrm{CO}$ emission of biodiesel compared to diesel is likely due to oxygen content inherently present in the biodiesel which helps in the more complete oxidation of fuel. Further it can be seen that volume of $\mathrm{CO}$ initially decrease but increase at full load indicating better burning conditions at higher temperature assisted by improved spraying qualities with uniform charge preparations of biodiesel.

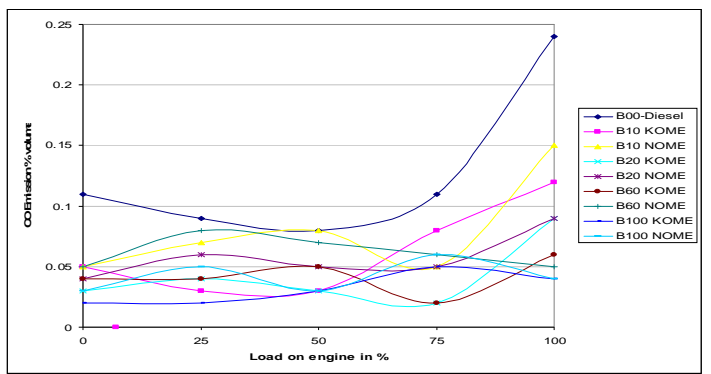

Figure 7 Comparison of variation of $\mathrm{CO}$ emission with load on engine

5.7 Exhaust gas emission of Hydrocarbon (HC)

The variations of $\mathrm{HC}$ emission for diesel and biodiesel are shown in the figure. The emissions of unburnt hydrocarbon for biodiesel exhaust due to lower than that of diesel fuel the increased gas temperature and higher cetane number of biodiesel could be responsible for this decrease. Higher temperature of burnt gases in biodiesel fuel helps in preventing condensation of higher hydrocarbon reducing unburnt HC. The higher cetane number of biodiesel results decrease in $\mathrm{HC}$ emission due to shorter ignition delay.

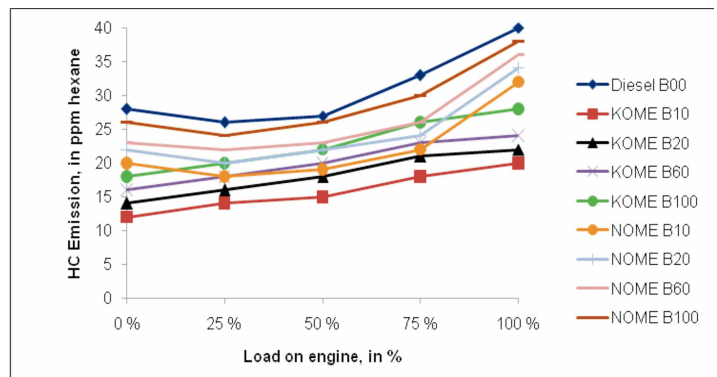

Figure 8 Comparison of variation of $\mathrm{HC}$ emission with load on engine

\subsection{Injection pressure}

Experimental investigations have been carried to examine the performance of the engine at the manufacturers rated speed with the injection pressures of $180 \mathrm{bar}, 200$ bar and 220 bar at the static injection timings of $24^{0}$ BTDC at compression ratio of 16.5. It was observed that as injection pressure increases brake thermal efficiency, BTE, increases for all fuels. Although it was seen that performance of engine is optimum at injection pressure of 200 bar and falls with further increase in injection pressure. At low injection pressures of 180 bar the BTE is lowest possibly due to the coarser size of fuel particles and lower depth of penetration in the combustion chamber resulting in longer time for combustion. When the injection pressure is increased to 200 bar the better mixing and proper utilization of air converted more heat into the useful work resulting in higher BTE.

When injection pressure is further increased to 220 bar the BTE decreased as against the normal trend. The probable cause can be attributed to the large pressure difference between the cylinder and the injection producing too high turbulence with fuel spray striking the colds walls of combustion chamber absenting the combustion process lowering the efficiency. The fuel injector nozzle with three holes $(0.16 \mathrm{~mm})$ was found coking (carbon deposits) due to higher injection pressures. It can be overcome by frequent cleaning of nozzle. The fuel droplets size and the combustion are governed by injection pressure, nozzle hole size, nozzle type and geometry [26]. This may require further separate research to investigate these parameters with the results.

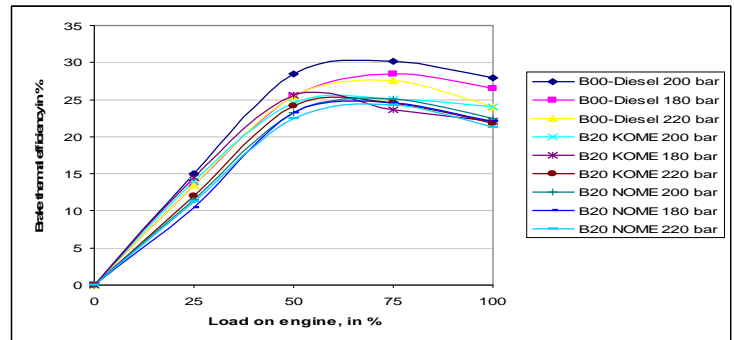

Figure 9 Comparison of variation of brake thermal efficiency at various injection pressures

\subsection{Specific gravity}

The density (a function of specific gravity) of biodiesel varies in a curvilinear fashion as the concentration of biodiesel in blend is increased in relation to the diesel fuel. Simple mathematical interpolation method is used to determine accurate blend density.

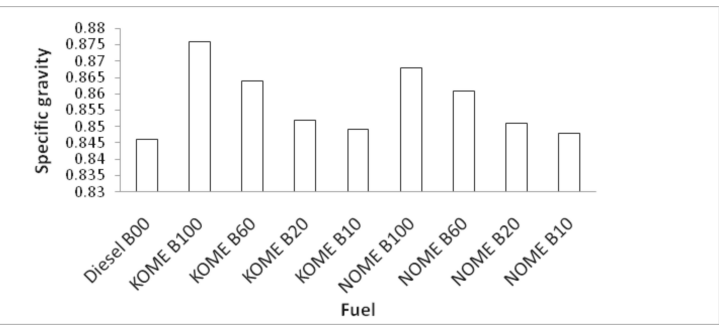

Figure 10 Comparison of variation of specific gravity with various fuels

\section{CONCLUSIONS}

Performance and emissions of diesel engine fueled with blends of biodiesels of karanja and neem with diesel fuel 
Performance and Emissions of c.i. Engine using Blends of Biodiesel and Diesel at Different Injection Pressures

are experimentally investigated. The results of study may be summarized as follows:

- Karanja and neem based biodiesels can be directly used in diesel engines without any modifications.

- $\quad$ The performance is slightly reduced while brake specific fuel consumption is increased when using biodiesels.

- The brake thermal efficiency of B10, B20 and B60 are better than B100 but still inferior to that of diesel.

- Compared with conventional diesel, exhaust emissions of $\mathrm{CO}$ and $\mathrm{HC}$ are reduced while $\mathrm{NO}_{\mathrm{x}}$ emissions are increased with biodiesel and its blends with diesel.

- The availability of abundant resources and environmental friendly emissions are recognized as strength of biodiesels leading them to potential candidates as alternative fuels.

- However further investigations to explore the knowledge of dynamics combustion with biodiesel as fuel is needed for the better optimization.

\section{ACKNOWLEDGEMENTS :}

The first author expresses his sincere gratitude to the Director General, MIT, Aurangabad for extending the laboratory facilities and the continuous support to carry out the research work in the Internal Combustion Engines laboratory.

\section{REFERENCES}

[1] Ramdhas A.S., Jayaraj S., Murleedharan C., "Use of vegetable oil as I.C. engine fuels - a review", Renewable Energy, 29 (2004), $727-$ 742

[2] Allen C.A.W., et al, "Predicting Viscosity of Biodiesel Fuel from fatty acid ester Composition", Fuel 78, (1999), 1319-1326.

[3] Masjuki H. H. et al, "Experimental Evaluation of an Unmodified Diesel Engine using Bio Diesel with Fuel Additive", IEEE (2006), 96-99.

[4] Lang X. et al, "Preparation and characterization of biodiesel from various Bio oils", Bioresource Technology, 80 (2001), 53-62.

[5] Barnwal B.K., Sharma M.P., "Prospects of biodiesel production from vegetable oils in India." Renewable and Sustainable Energy Reviews, 9 (2005), 363-378.

[6] Naidu B.S.K., "Indian scenario of renewable energy for sustainable development", Energy Policy, 24 (1996), 575-581.

[7] http://www.biodiesel.org/resources/reportsdatabase/

[8] Lios E., "Definition of Biodiesel" Fuel, 86 (2007), 1212-1213

[9] Sumathi S., Chai S.P., Mohamed A.R., "Utilization of oil palm as a source of renewable energy in Malaysia" Renewable and Sustainable Energy Review, 2007.
[10] Frondel M., Peters J., "Bio Diesel: A new oil Dorado?" Energy Policy, 35 (2007), 1675-1984.

[11] Agrawal A.K., Das L.M., "Bio diesel development and characterization for use as a fuel in CI engine", ASME, 123 (2001), 440-447.

[12] Goering C.E. et al, "Fuel properties of eleven vegetable oils", Tran ASAE, 25 (4-6), 1982.

[13] Senthil Kumar M et al," A Comparative Study Of Different Method Of Using Animal Fat as a Fuel In CI Engine", ASME Journal of Engineering for Gas Turbines and Power, 128 (2006), 907-914.

[14] Ganapathy T. et al," An analytical and experimental study of performance on jatropha bio-diesel engine", Thermal Science Vol.13,p.p. 69-82, (2009)

[15] Ravi Kumar P et al ' Comparison of performance characteristics of DI Diesel Engine using blends of cotton seed oil, palm oil and neem oil with diesel' International Journal of Engineering Research and Industrial Applications, Volume 3,Number 1(2010), 41-50.

[16] Lin YF, Wu Yoping, Chang Tang, "Combustion Characteristics Of Waste Oil Produced Biodiesel / Diesel Fuel Blends", Fuel 86 (2007), 1772-1780

[17] Raheman H., Phadtare A.G., "diesel engine emissions and performance from blends of karanja methyl ester and diesel", Biomass and bioenergy, 27 (2004), 393-397

[18] Nabi Md Nuran et al., "Improvement of engine emissions with conventional diesel fuel and diesel biodiesel blends", Bioresource Technology, 97 (2006), 372-378.

[19] Sundarapandian S., Devaradjane G., "Performance and Emission Analysis of Biodiesel operated CI Engine", Journal of Engineering, Computing and Architecture Vol-I (2007).

[20] He Y., Bao V.D., "Study on rapeseed oil as alternative fuel for a single cylinder diesel engine", Renewable Energy, 28 (2003), 14471453.

[21] Carraretto C. et al, "Biodiesel as alternative fuel: experimental analysis and energetic evaluations." Energy, 29 (2004), 2195-2211.

[22] He Y, Bao Y.D., "Study of Cotton Seed Oil as a Partial Substitute for Diesel Oil for Single Cylinder Diesel Engine", Renewable Energy, 30 (2005), 805-813.

[23] Yaliwal V.S. et al "Production and utilization of renewable liquid fuel in a single cylinder foure stroke direct injection compression ignition engine", International Journal of Engineering Science and Technology vol. 2(10), 5938-5948, (2010).

[24] Raghavan Vasudevan et al "Investigation of combustion characteristics of bio-diesel and its blends", Combustion Science and Technology, vol.181, 877-891(2009).

[25] Venkateswara Rao T. et al "Experimental investigation of pongamia, jatropha and neem methyl esters as bio-diesel on CI engine", JJMIE, Vol.2, p.p-117-122 (2008.)

[26] Heywood J.B., Internal Combustion Engines, McGraw Hill 1988

[27] Plint Michael and Martyr Anthony "Engine Testing Theory and Practice", Second Edition, SAE International, (1999)

[28] Ganesan V," Computer Simulation of Compression-Ignition Engine Processes", Universities press. 